\title{
Metals distribution on the surface of quartz fiber filters used for particulate matter collection
}

\author{
Kamila Widziewicz ${ }^{1,2 *}$, Krzysztof Loska ${ }^{1}$, Wioletta Rogula-Kozłowska² \\ ${ }^{1}$ Silesian University of Technology, Poland \\ Faculty of Energy and Environmental Engineering \\ ${ }^{2}$ Institute of Environmental Engineering of the Polish Academy of Sciences, Poland \\ *Corresponding author's e-mail: kamila.widziewicz@ipis.zabrze.pl
}

\begin{abstract}
Keywords: PM2.5, metals, quartz fiber filters, homogeneity, distribution.
\end{abstract}
\begin{abstract}
Presented study aimed to determine metals distribution on the quartz fiber filters surface coated with particulate matter by using high and low-volume samplers. The distribution pattern was tested using two different sub-sampling schemes. Each sub-sample was mineralized in the nitric acid in a microwave oven. An analysis was performed by means of atomic absorption spectroscopy with electrothermal atomization GF-AAS technique, and the determined elements were: $\mathrm{As}, \mathrm{Cd}, \mathrm{Pb}$ and $\mathrm{Ni}$. A validation of the analytical procedure was carried out using NIES 28 Urban Aerosols standard reference material.

It was assumed that metal is distributed uniformly if its normalized concentrations on a single sub-sample is within $\pm 15 \%$ of the mean concentration over the whole filter. The normalized concentrations values exceed this range, indicating a non-homogenous metals distribution. There were no statistically significant differences in metals concentrations between particular sub-samples in the function of its position along the filters diameter.
\end{abstract}

\section{Introduction}

The Polish air monitoring network (monitoring system of air quality) consists of selected monitoring stations belonging to The Regional Inspectorates of Environmental Protection (RIEPs), under the supervision of the Chief Inspectorate of Environmental Protection (CIEP) (Kobus et al. 2007). Each of them collects measurement data for a number of pollutants, including particulate matter (PM) (Leśniok 2011) and gaseous pollutants: $\mathrm{NO}, \mathrm{NO}_{2}, \mathrm{SO}_{2}, \mathrm{CO}, \mathrm{O}_{3}$. The measurement plan also comprises a concentration of selected PM compounds: organic/inorganic carbon, watersoluble ions, $\mathrm{Pb}, \mathrm{Cd}, \mathrm{Ni}, \mathrm{As}, \mathrm{Cr}, \mathrm{Zn}$, polycyclic aromatic hydrocarbons (PAHs). The range of pollutants measured at each station and its threshold limits are presented in the Regulation of the Ministry of Environment of 24 August 2012 concerning evaluation of substances levels in the air and in the Regulation of the Minister of Environment of 26 January 2010 on the reference values for certain substances in the air (the Regulation of the Ministry of Environment of 24 August 2012 concerning evaluation of substances levels in the air and the Regulation of the Minister of Environment of 26 January 2010 on the reference values for certain substances in the air). Those legislative documents and standards (PN-EN 12341:2006a, PN-EN 14907:2006b) clearly describe methodology, process validation, and other requirements for air quality monitoring. The only failing in those regulations is a lack of a state defining the exact method of dust subsampling for chemical composition testing. Therefore the measurements are executed by different subsampling schemes and different times of averaging. In order to obtain comparable data about chemical composition of particulate matter among monitoring stations, measurements should be performed by following the same procedures and subsampling schemes. A number of parameters should be measured from a single PM filter (to assess the PM effects on human health and for tracing the PM origin (Viana et al. 2008)), and therefore it must be subsampled. It is done by filters division into a certain size pieces. The spatial uniformity of aerosol at individual parts of filter ensures that any single sub-sample is representative for a filter as a whole. The most common method for the filters subsampling includes: cutting circles, rectangles or dividing filters centrifugally into four or eight equal sectors using non-ferrous, usually ceramic, cutting tools. RIEP laboratories most frequently use two methods of filters cutting, first is known as "cake-shape method" (cutting sections enclosed by two radii and an arc) and the second one is the "punching method" (cutting circles from the filter outer or inner edge). There are no recommendations for the filters subsampling at Polish air monitoring network (Prządka et al. 2012). Each of the RIEP laboratories applies its own way of filters division. For example, for water-soluble anions $\left(\mathrm{SO}_{4}^{2-}, \mathrm{NO}_{3}^{-}, \mathrm{Cl}^{-}\right)$and cations $\left(\mathrm{NH}_{4}^{+}, \mathrm{Na}^{+}, \mathrm{K}^{+}, \mathrm{Mg}^{2+}\right.$, $\mathrm{Ca}^{2+}$ ) measurement purposes, a few laboratories incorporated into Polish air monitoring network cut out subsamples with an area equal to one eighth or one quarter of the total filter surface (unpublished source), while other punch circles with 
a diameter equal to $47 \mathrm{~mm}$ (IOŚ-PIB, 2011). Considering the heterogeneity of PM material (Finlayson-Pitts and Pitts 1986), it appears that variations in the concentrations of the individual components in different parts of the filter can be significant. Intuitively, it can be assumed that they will grow with the mass of dust collected on the filter. Thus, it seems that the greatest variations in the concentrations of several components of the dust in different parts of the same filter will be more marked in the case of samples collected using high volume samplers. The weight of daily-collected dust samples in the case of high volume sampler (nominal air flow $30 \mathrm{~m}^{3} / \mathrm{h}$ ), reach up to $250 \mathrm{mg}$ (Rogula-Kozłowska et al. 2013), while samples collected daily by using low volume samplers (nominal air flow $2.3 \mathrm{~m}^{3} / \mathrm{h}$ ) weigh no more than $30 \mathrm{mg}$ (PN-EN 12341:2006a).

Given the requirements for data quality control, the Polish air monitoring laboratories should establish unified method for the filters subsampling, that will be fit for its intended use in a measurement process.

This paper presents the results of nickel, cadmium, lead and arsenic distribution on the quartz fiber filters used in high- and low-volume samplers relevant according to the preferred method for the filters subsampling.

\section{Experimental part of the study}

\section{Sample collection}

Filters used in the experiment were derived from different sampling campaigns, in urban areas of Silesia. The average sampling time was $24 \mathrm{~h}$. Ambient particles with an aerodynamic diameters not greater than $2.5 \mu \mathrm{m}\left(\mathrm{PM}_{2.5}\right)$ were collected with a high volume sampler (model Digitel DHA-80; nominal air flow rate: $30 \mathrm{~m}^{3} / \mathrm{h}$ ) equipped with $\mathrm{PM}_{25}$ measuring head onto $\varnothing 150 \mathrm{~mm}$ Whatman quartz fiber filters (QMA, Cat. no. 1851-150) at the urban background site in southern Poland (Katowice). Additionally $\mathrm{PM}_{2.5}$ particles were collected on $\varnothing 47 \mathrm{~mm}$ Whatman quartz fiber filters (QMA, Cat. no. 1851-047) with low-volume air samplers (nominal air flow rate: $2.3 \mathrm{~m}^{3} / \mathrm{h}$ ) at the urban background sites in two Silesian cities (Bielsko-Biała and Częstochowa) and at the traffic site in Katowice. Sampling points meet the conditions for an urban background and traffic sites described in EC, 2008 (Directive 2008/50/EC).

The mass of the sampled dust was determined gravimetrically (Sartorius balance, resolution $0.01 \mathrm{~g}$ for $\varnothing 150$ $\mathrm{mm}$ filters and microbalance with a resolution $1 \mu \mathrm{g}$ for $\varnothing 47$ mm filters) according to the CSN EN 14907 standard (BS EN 14907:2006). Before each weighing, filters were conditioned for at least 48 hours at the air temperature of $20 \pm 1^{\circ} \mathrm{C}$ and air relative humidity of $50 \pm 5 \%$ in the weighing room. The mass of dust loadings on the filters subsamples was weighed using Radwag microbalance with a resolution $1 \mu \mathrm{g}$.

\section{Sample treatment}

To determine the homogeneity of elements, deposition filters were cut with ceramic scissors and special stainless punch according to the scheme presented in Table 1. Two types of sub-sample were prepared. Sub-sample (a) was taken by cutting $\varnothing 150 \mathrm{~mm} \mathrm{PM}_{25}$ filters, into 20 rectangular fragments (single fragment area was equal to $6.25 \mathrm{~cm}^{2}$ ). Sub-sample (b) was taken by punching three circles from the $\varnothing 47 \mathrm{~mm} \mathrm{PM}_{25}$ filters, each one with a surface equal to $1.39 \mathrm{~cm}^{2}$. The first punch was located at the center of the filter and two others in a distance from the filter's outer edges.

Table 1. Sites and sampling pattern for $\mathrm{PM}_{2.5}$

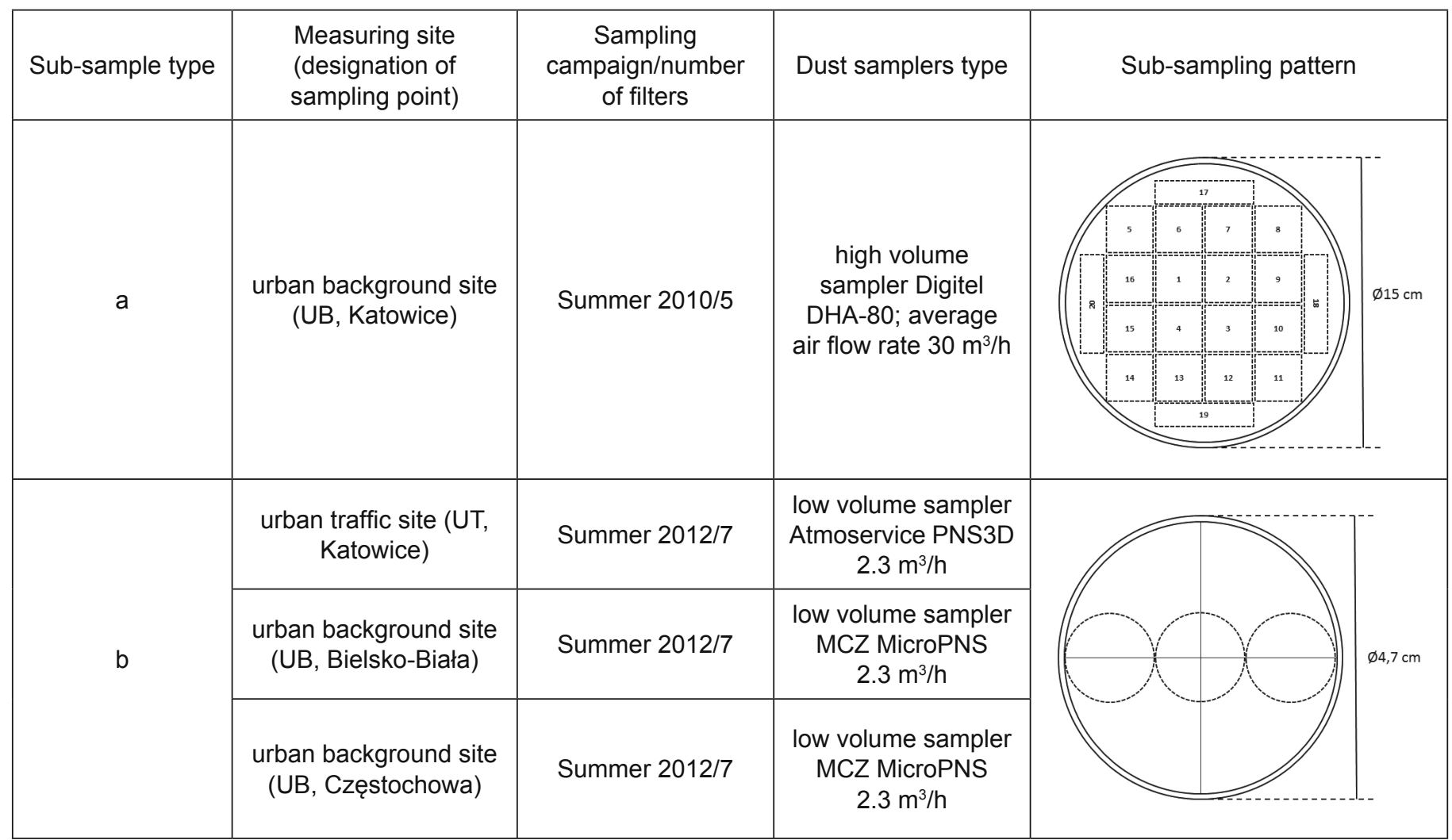




\section{GF-AAS analysis}

Sub-samples were put into the reaction vessels and underwent overnight digestion in $3 \mathrm{~cm}^{3}$ of $65 \%$ nitric acid (Baker). Further mineralization was carried out in Teflon PTFE vessels with the $1000 \mathrm{~W}$ power for 8 minutes in the MLS 1200 MEGA microwave digestion system. After digestion the sub-samples were transferred into $25 \mathrm{~cm}^{3}$ volumetric flasks, using the deionized water, and filled to volume. Metals contents were measured by SpectrAA 880 Zeeman AAS equipped with GTA100 graphite furnace. All reagents were of an analytical grade. Standards solutions were prepared daily by diluting $1000 \mathrm{mg} / \mathrm{l}$ of standard stock solutions (Merck). A similar procedure was used for the standard reference material. About $50 \mathrm{mg}$ of the NIES 28 Urban Aerosols material was weighted onto a blank quartz filter and digested, although the acid volume was $4 \mathrm{~cm}^{3}$ and the average time was 15 minutes. After digestion the SRM was transferred into $100 \mathrm{~cm}^{3}$ volumetric flask. The statistical analysis was carried out using the Statistica ver. 9 (StatSoft) software.

The correctness of the methodology was verified using reference material CRM 28 Urban Aerosols. Considering the complexity of PM composition the recoveries for As, Cd, $\mathrm{Pb}$ and $\mathrm{Ni}$ as well as method repeatability (RSD\%) were fully satisfactory (Table 2).

\section{Results and discussion}

The $24 \mathrm{~h}$ ambient mass concentrations of $\mathrm{PM}_{2.5}$ were in the range from $14.53 \mu \mathrm{g} / \mathrm{m}^{3}$ to $70.72 \mu \mathrm{g} / \mathrm{m}^{3}$, with the highest values for the samples collected at the urban traffic site in Katowice due to its close proximity to the motorway, where traffic emission had a large contribution to the particulate matter concentration (IOŚ-PIB, 2011). The differences among $24 \mathrm{~h}$ samples concerned not only the $\mathrm{PM}_{25}$ mass but also its elemental composition. The highest $24 \mathrm{~h}$ concentration, over $66 \mathrm{ng} / \mathrm{m}^{3}$, was for $\mathrm{Pb}$, while the lowest $0.18 \mathrm{ng} / \mathrm{m}^{3}$ was found for As. Those levels were generally similar compared with recent reports concerning metals-air pollution in Upper Silesia (Rogula-Kozłowska et al. 2011, Rogula-Kozłowska et al. 2013). This brief overview shows that samples selected for the distribution analysis were collected at different monitoring stations and sampling campaigns, which helped to avoid assessing the distribution pattern under a narrow variability range. The literature data regarding the nature of PM and PM associated metal distribution over the filter surface show inconsistent results. Some authors document homogeneity in the surface distribution of PM-related metals (Moura et al. 1987, Low et al. 1990), while others argue for distributional heterogeneity, which applies not only to metals but also to non-metallic PM compounds, such as ions (Marrero et al. 2005,
EPA 2008, Brown et al. 2009, Brown and Keates 2011). In most cases this heterogeneity is found between the samples collected on inner and outermost fragments of the filter (Anglov et al. 1993, Steinhoff et al. 2000). In this work metals distribution was tested in the function of sub-sample position along the filter radius (Table 1 ). The analysis was started by testing $\mathrm{PM}_{2.5}$-bound metals distribution over $15 \mathrm{~cm}$ in diameter filters, cut into 20 rectangular sub-samples. Those sub-samples were divided into three groups: center, middle and edge group. Fragments 1-4 formed the center group, pieces from 5 to 16 created the middle group, while fragments 17-20 were classified as the edge one. The null hypothesis stated that significant differences occur in the mean elements concentrations among separate groups. Because the concentration data showed non normal distribution (Shapiro Wilk test, $\mathrm{p}<0.05$ ), in order to check the differences in elements contents over the quartz fiber filters, Kruskal-Wallis one-way ANOVA test was used. The effect was not statistically significant $(\mathrm{p}>0.05)$, and therefore it was assumed that $\mathrm{Cd}$, $\mathrm{Pb}, \mathrm{Ni}$ and As concentrations do not change while moving away from the filter center. Figure 1. presents an example of $\mathrm{PM}_{2,5}$-bound metals distribution on $\varnothing 15 \mathrm{~cm}$ filters.

In terms of sub-sampling, any heterogeneity in PM mass loadings over the filter or any weighing errors, influenced measured metals contents. To check this influence on metals spatial distribution, the analysis was performed bidirectionally, including two methods for PM weight measurements. The first method involved gravimetric determination of PM mass (distribution by weight). It was done by subtracting the average mass of a single sub-sample after digestion from its initial weight. The second method used "predicted mass", which was calculated by referring the area of a single sub-sample to the entire filter surface with a known mass (distribution by surface).

For the graphical presentation of metals distribution between those two methods, the mean concentration for each element over 20 positions was calculated, and each element concentration was normalized to this value. The concentrations of $i$ elements in $j$ fragments (sub-samples) for $k$ filters $X_{i j k}$ were determined and calculated to the normalized concentrations $\hat{X}_{i j k}$, as follows:

$$
\hat{X}_{i j k}=\frac{X_{i j k}}{\bar{X}_{i k}}
$$

where,

$i$ : $\quad$ corresponds to each measured element $(k=1-4)$;

$j$ : $\quad$ corresponds to each position (disc cut from each filter) ( $k=1-20)$;

$k$ : $\quad$ corresponds to the filters considered for the study $(k=1-5)$;

$\bar{X} i k$ : is the average concentration of element $i$ for the subsamples taken from filter $k$.

Table 2. Reference material CRM 28 Urban Aerosols accuracy test results, mg/kg $(\mathrm{N}=6)$.

\begin{tabular}{|c|c|c|c|c|}
\hline Metal & $\begin{array}{c}\text { Measured value } \\
(\mathrm{n}=6)\end{array}$ & Certified value & Recovery (\%) & $\begin{array}{c}\text { Precision } \\
\text { RSD }(\%)\end{array}$ \\
\hline $\mathrm{As}$ & $80.45 \pm 3.38$ & $90.2 \pm 10.70$ & 89 & 4.82 \\
\hline $\mathrm{Cd}$ & $5.97 \pm 0.29$ & $5.60 \pm 0.43$ & 107 & 4.94 \\
\hline $\mathrm{Pb}$ & $375.88 \pm 20.20$ & $403 \pm 32$ & 93 & 6.37 \\
\hline $\mathrm{Ni}$ & $52.17 \pm 3.32$ & $63.8 \pm 3.40$ & 106 & 6.37 \\
\hline
\end{tabular}



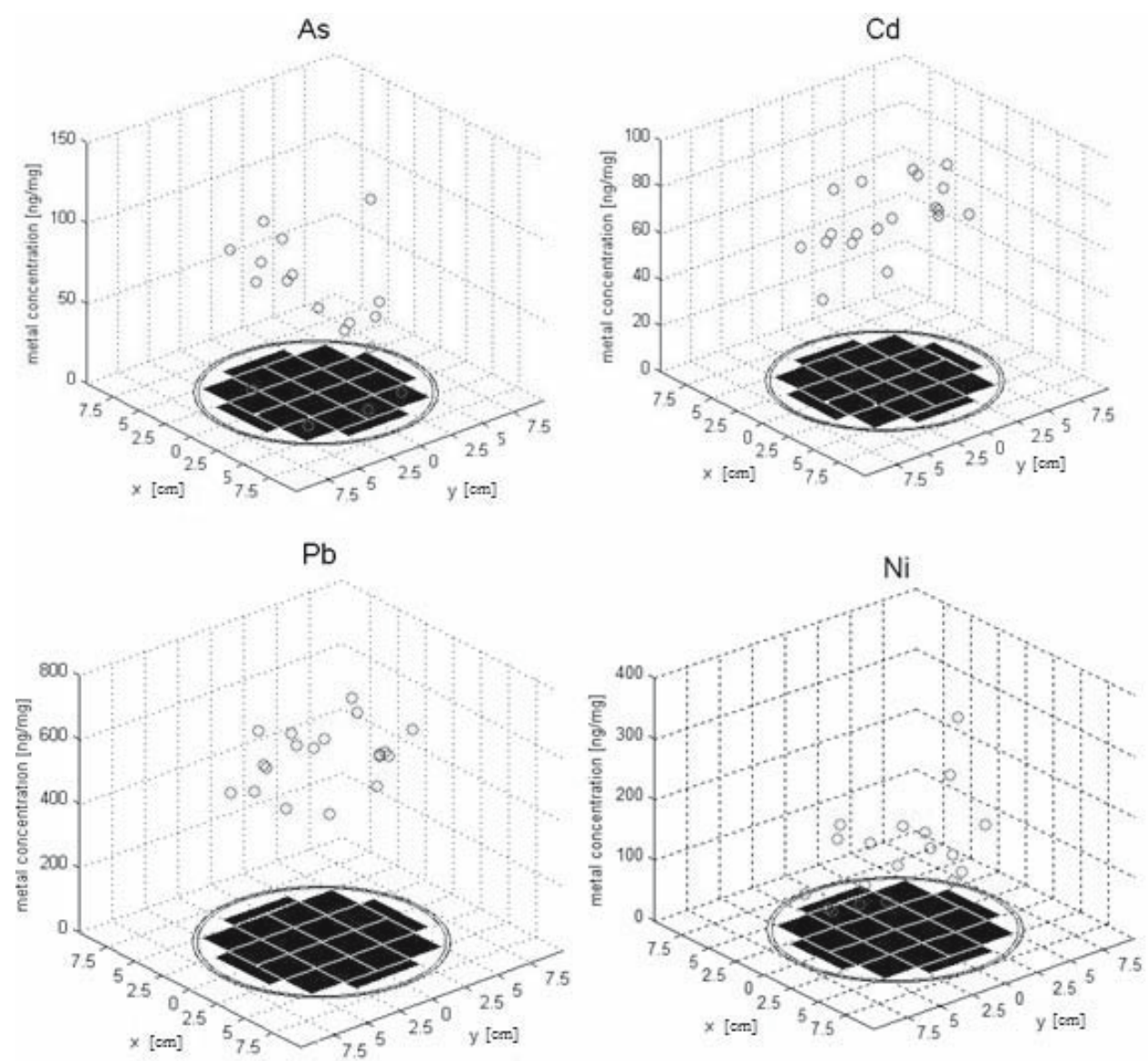

Fig. 1. Raw data presenting an examples of $\mathrm{PM} 2.5$-bound $\mathrm{As}, \mathrm{Cd}, \mathrm{Pb}$ and $\mathrm{Ni}$ distribution over quartz fiber filters

The obtained results were presented on scatter plots, separately for each element (Figure 2).

Much higher dispersion in metals distribution, well beyond $0.85-1.15$ uniformity level, was found when PM mass was calculated gravimetrically. This appears to be due to the weighing biases, which occur at the stage of subsamples digestion. During the acid digestion, filters partly undergo physical degradation as a result of high pressure and temperature. The PM mass calculated by subtracting the filter mass before and after mineralization was therefore increased by the filter weight-loss. This affected PM mass measurements, thereby falsifying the actual concentrations of metals on particular sub-samples. In a few sub-samples particulate matter was permanently connected to the filter material and thereby incompletely digested (Yang et al. 2012). In that case, PM mass value was understated, which also contributes to the metals measurement errors. Another drawback connected to the "distribution by weight" measurement method is the need for time-consuming sub-samples drying (before and after digestion) to the constant weight, and its multiple weighing. The ideal solution would be probably to calculate the weight of dust on the individual sub-samples as a difference between the mass of loaded subsample before mineralization and the mass of blank subsample (without dust) calculated from the known area of the whole filter (this assumption is based on the information provided by the filters producer that the mass of the single $\mathrm{mm}^{2}$ of the filter material is equal). This method, however, could not be applied in the present study, because of the inaccuracy of the cutter tool. The surface of a single loaded subsample, cut from the filter, was not perfectly equal to the calculated surface of the blank subsample.

Due to the presence of an intermediate PM digestion stage "distribution by weight measurement" method is not suitable for assessing metals spatial distribution on the filters surface. The more proper approach is to address the concentration measurements to the predicted PM mass value, calculated by referring the area of a single sub-sample to the entire collection surface, with a known mass. By knowing the whole filter surface and the PM mass deposited on this surface, as well as the area of a single sub-sample cut from this surface, one can calculate the predicted mass of the dust adsorbed on any filter fragment. The disadvantage of this approach is an assumption that particulates deposited on the filter surface are distributed uniformly.

A numerical dispersion of metals over the filters area was illustrated by the relative standard deviation RSD\% value. Low et al. (1990) and Dreetz\&Lund (1992), assumed that an element is distributed uniformly, when its RSD\% does not exceed $15 \%$ of its average content on the whole filter surface. In this study the relative standard deviation (RSD\%) between 20 sub-samples was calculated by dividing the standard deviation from 20 concentration measurements by an average metal concentration for a single filter. The RSD \% values were as follows: $21-68 \%$ for As, $14-55 \%$ for $\mathrm{Cd}, 12-47 \%$ for $\mathrm{Pb}$ and $23-63 \%$ for $\mathrm{Ni}$ (distribution by weight) and $12-35 \%$ for As, $3-20 \%$ for $\mathrm{Cd}, 1-9 \%$ for $\mathrm{Pb}$ and $26-59 \%$ for $\mathrm{Ni}$ (distribution by surface). By comparing the presented results (Figure 2 ), with $15 \%$ criteria, we concluded that $\mathrm{Pb}, \mathrm{Cd}, \mathrm{Ni}$ and $\mathrm{As}$ 

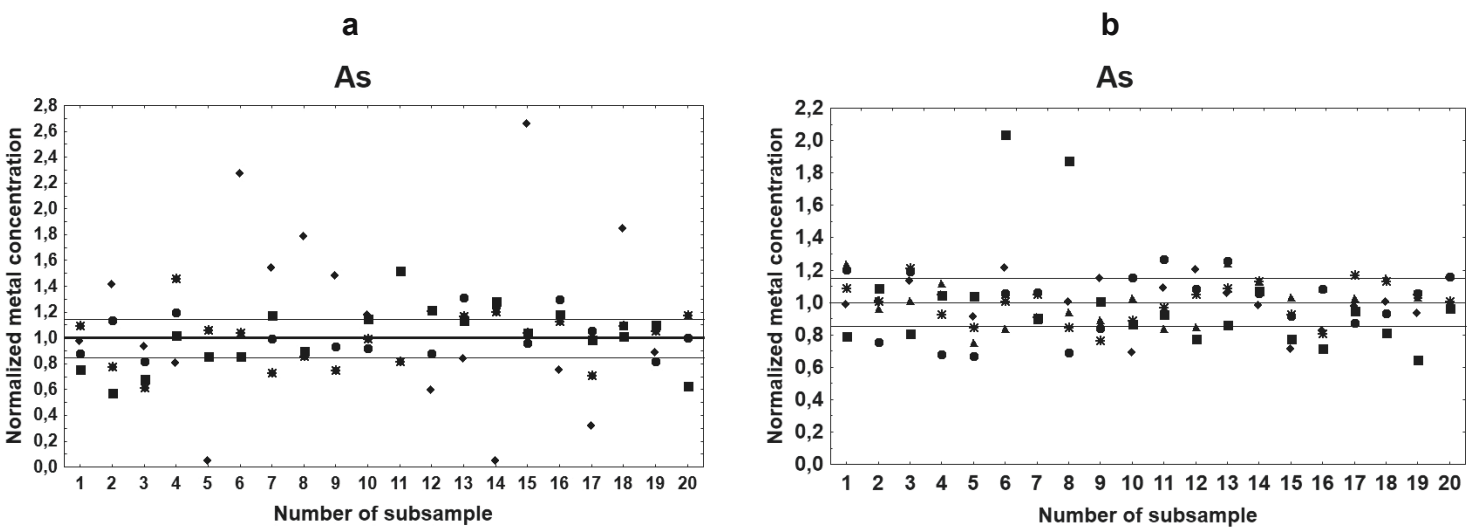

Cd

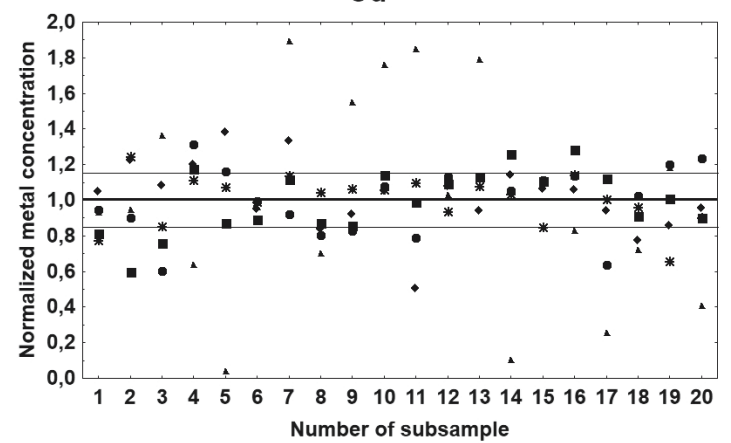

Cd

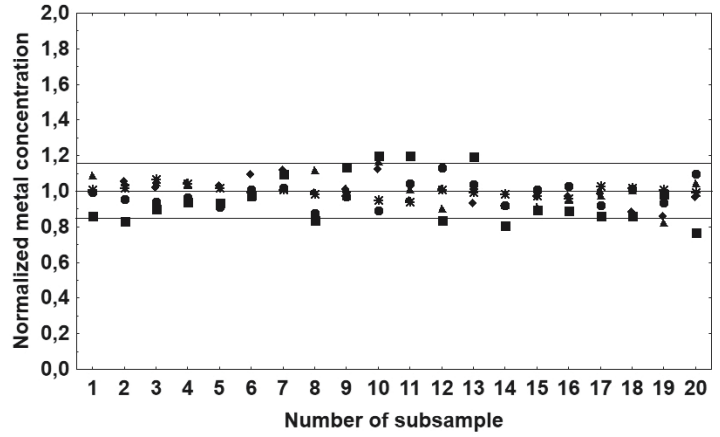

$\mathrm{Pb}$

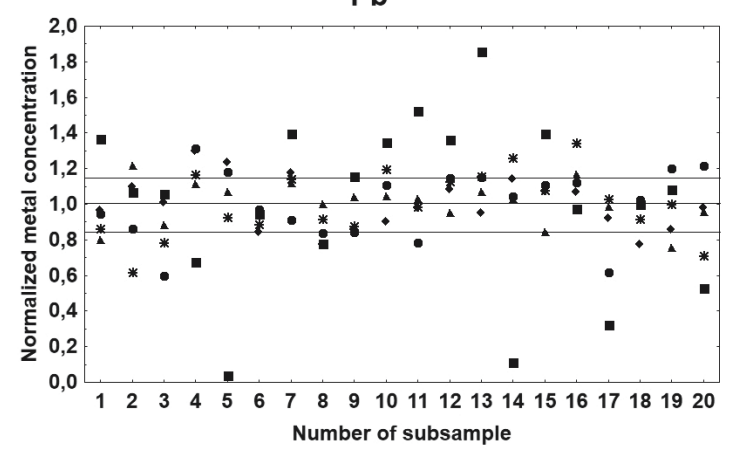

$\mathrm{Pb}$

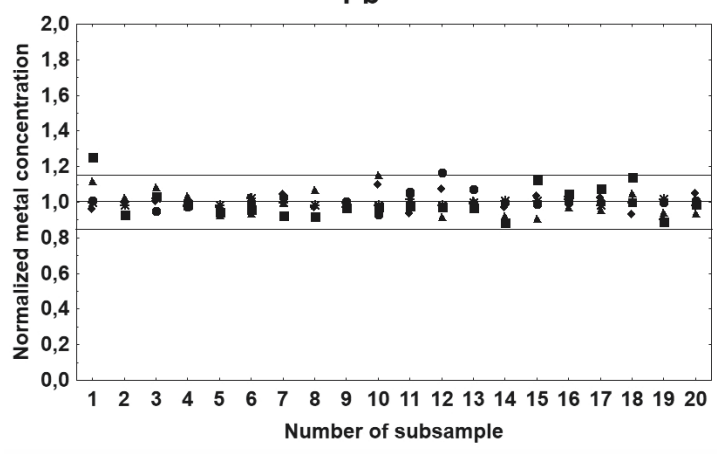

$\mathrm{Ni}$
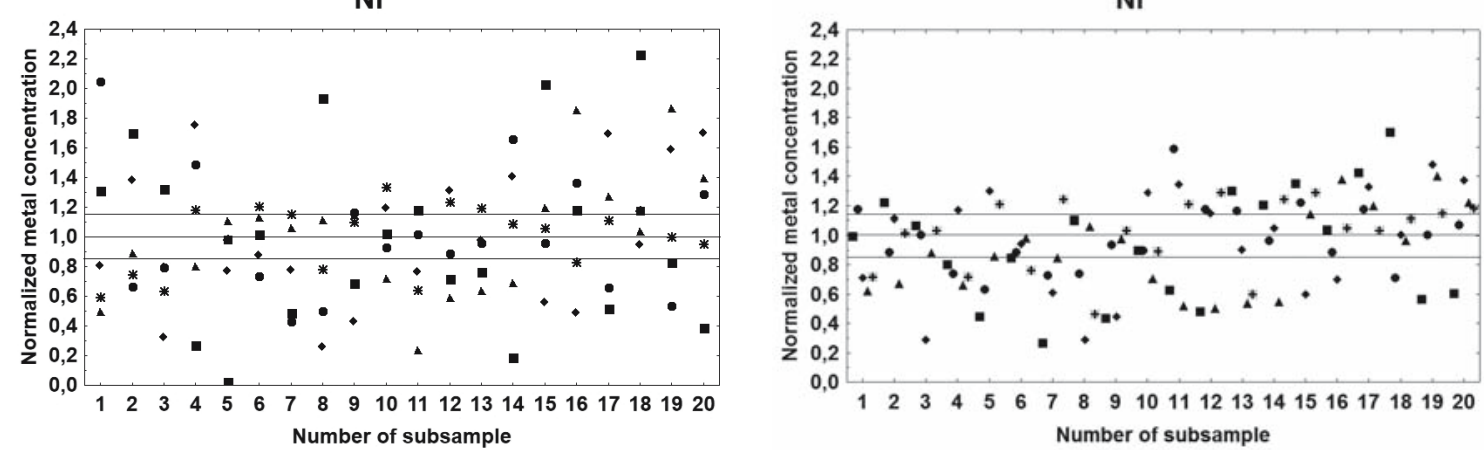

Fig. 2. Variability in metals (As, $\mathrm{Cd}, \mathrm{Pb}$ and $\mathrm{Ni}$ ) distribution over 20 subsamples cut from five $\varnothing 15 \mathrm{~cm}$ filters, calculated according to equation 1. Subsamples cut from each filter are marked by a different tag. Distribution by weight measurements (a), distribution by surface measurements (b)

distribution over the quartz fiber filters was non-uniform. $\mathrm{Pb}$ and $\mathrm{Cd}$ showed the most homogenous pattern, while the larger heterogeneity was observed for As and Ni. Greater dispersion of As and Ni was explained by low levels of these elements in the particulate matter (relatively low analytical signal). Similar results were obtained by Pöykiö et al. (2003). He indicated non-uniform distribution of heavy metals over the TSP filters, reflected by the following $\mathrm{RSD}^{\circ}$ values: $5.4-33.9 \%$ for $\mathrm{Cr}$,
7.50-35.0\% for $\mathrm{Ni}, 3.6-25.9 \%$ for $\mathrm{Cu}$, and $6.6-19.9 \%$ for $\mathrm{Fe}$. In his study these relatively large $\mathrm{RSD} \%$ values were explained by the non-uniform PM load over the filter surface, connected with the phenomena of an uneven air intake through the air samplers. Among other possible reasons for non-homogenous metals distribution authors usually mention a loss of PM material due to filters improper transport or storage (Chartier and Weitz 1998, Zdrojewski et al. 1973). 

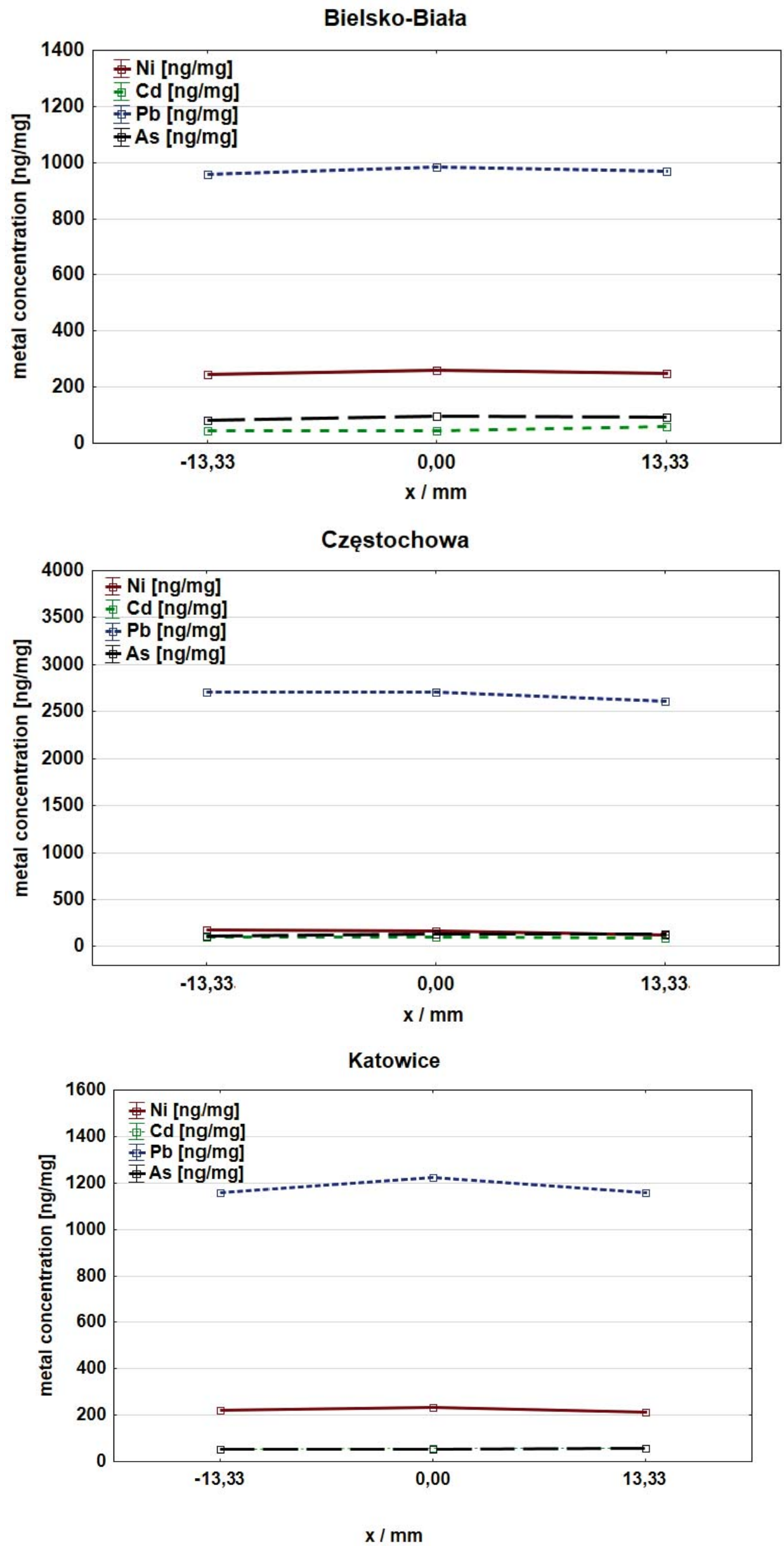

Fig. 3. As, $\mathrm{Cd}, \mathrm{Pb}$ and $\mathrm{Ni}$ distribution over the $\varnothing 47 \mathrm{~mm} \mathrm{PM}_{25}$ quartz fiber filters collected at Bielsko-Biała, Częstochowa and Katowice sites, where $x$ axis is a distance $[\mathrm{mm}]$ from the filter center 
To check for differences in metals contents between filter's center and outer edge, the $\varnothing 47 \mathrm{~mm}$ PM2.5 filters were used. Because of filters small area it was not possible to perform such detailed distribution analysis like in the case of $15 \mathrm{~cm}$ filters. The minimum sub-sample area was cut from $47 \mathrm{~mm}$ filters, which guaranteed a desired absorbance signal (about 0.2 ) was $1.2 \mathrm{~cm}^{2}$, which precluded cutting more than 3 circles from one filter. The concentration data from the outer edges was compared with the metals contents in the filter's center. The differences in metals concentration between center and outer sub-samples were $6.8 \%, 5.5 \%, 2.96 \%, 7.79 \%$ for $\mathrm{As}, \mathrm{Cd}, \mathrm{Pb}$ and $\mathrm{Ni}$ respectively. Similar distribution pattern was observed for filters collected at Katowice, Bielsko-Biała and Czestochowa sites (Figure 3). The largest heterogeneity was observed for As and $\mathrm{Ni}$, which was in a good agreement with the results obtained for $\varnothing 15 \mathrm{~cm}$ PM2.5 filters, once again indicating spatially non-uniform metals distribution between particular sub-samples. We can suspect that trends observed here for metals will be representative for other PM compounds, such as, for example ions, as they generally depend on PM mass distribution over the filters material.

\section{Conclusions}

The obtained results showed that $\mathrm{As}, \mathrm{Cd}, \mathrm{Pb}$ and $\mathrm{Ni}$ spatial distribution over the filters surface was not uniform. The element which showed the largest departures from the mean concentration was nickel, while lead showed the greatest distributional uniformity. Although metals distribution was generally nonuniform, no significant differences were found, considering sub-sample distance from the filter center. Therefore, it might be suspected, that cutting any part of the filter is appropriate.

It was also found that the method used for calculating the weight of dust on a single sub-sample significantly influenced metals distribution. Relating the analytical signal to the PM mass calculated as the difference between filters weight before and after mineralization affects the real concentrations values, due to filters loss during digestion and leads to a larger distributional heterogeneity. A better approach in the metal distribution analysis using GT-AAS is, therefore, to address the analytical signal to the PM mass, calculated from the known filter area. Due to a destructive nature of intermediate mineralization step, GT-AAS is not applicable in the metals distribution analysis on PM filters. This type of analysis should be performed by using, for example, the Energy Dispersive X-ray Fluorescence (EDXRF) technique. It should, however, be emphasized that EDXRF can be successfully applied only in the elemental analysis of Teflon, polycarbonate or nylon filters.

The presented study does not allow to create a clear methodological recommendations regarding filters subsampling, although given the evidence for no preferential metals distribution on filters surface, we suppose that sub-sampling can be done freely. Sub-sampling by using the "cake-shape method" probably gives more representative results for the entire sample. It is also important, that in the case of filters with a large collection surface (for high-volume samplers) subsampling should cover, possibly, the largest area. When cutting small subsamples, the differences in PM composition between filter's center and edge may be significant. This applies especially to those components which are present in PM in very low concentrations, particularly metals. Cutting small subsamples, when necessary, should be done by selecting several sub-samples from a single filter, including, for example, a section from the center and a few sections from the filter's edge. Given the problems discovered, and the requirements for the PM data quality control, the laboratories integrated into Polish national air monitoring network should prepare a consistent and unified guide for the filters subsampling.

\section{Aknowledgements}

This study was financed by BKM-538/RIE-4/2013 financial support.

Samples from the urban background in Katowice were collected under a grant No. N N523 421037 financed by the Polish Ministry of Science and Higher Education carried out in the Institute of Environmental Engineering, PAS under the guidance of Dr. Krzysztof Klejnowski.

\section{References}

Anglov, J.T.B., Holst, E., Dyg, S. \& Christensen, J.M. (1993). Iron, manganese, copper and titanium in welding fume dust on filters for internal and external quality assurance, Fresenius Journal of Analytical Chemistry, 345, pp. 335-339.

Brown, R.J.C., Jarvis K.E., Disch, B.A., Goddard, S.L. \& Brown, A.S. (2009). Spatial inhomogeneity of metals in particulate matter on ambient air filters determined by LA-ICP-MS and comparison with acid digestion ICP-MS, Journal of Environmental Monitoring, 11, pp. 2022-2029.

Brown, R.J.C. \& Keates, A.C. (2011). Spatial inhomogeneity of anions in ambient particulate matter collected on air filters: Determination using a drift-corrected ion chromatography technique, Talanta, 84, pp. 918-923.

BS EN 14907:2006, "Ambient air quality - Standard gravimetric method for determining the mass fraction of PM2.5 particulate matter".

Chartier, K.L. \& Weitz, M.A. (1998). A comparison of filter types in the collection and gravimetric determination of airborne particulate matter less than 2.5 microns (PM2.5), Journal of the Air \& Waste Management Association, 48, pp. 1199-1203.

Directive 2008/50/EC of the European Parliament and of the Council of 21 May 2008 on ambient air quality and cleaner air for Europe.

Dreetz, C.D. \& Lund, W. (1992). Air-intake filters used for multi-element analysis of airborne particulate matter by inductively coupled plasma atomic emission spectrometry, Analitica Chimica Acta, 262, pp. 299-305.

EPA (2008). Laboratory Determination of Particle Deposition Uniformity on Filters Collected Using Federal Reference Method Samplers. (http://www.epa.gov/ttn/naaqs/standards/ pb/data/20081007LabDetermination.pdf (07.09.2015))

Finlayson-Pitts, B.J. \& Pitts, J.N. (1986). Atmospheric chemistry: fundamentals and experimental techniques, Wiley, New York 1986.

IOŚ-PIB (2011). The analysis of PM10 and PM2.5 ambient air pollution including its chemical composition and the influence of natural sources, Zabrze. Final report. (pp. 2-274) (http://www.gios.gov.pl/zalaczniki/artykuly/analiza_stanu zanieczyszczenia_PM10_2_5.pdf(07.09.2015)). (in Polish)

Kobus, D., Iwanek, J., Mitosek, G. \& Mill, W. (2007). Organization of air quality monitoring data collection in Poland. Review of available air quality data, Institute of Environmental Protection, Warsaw 2007.

Leśniok, M. (2011). Changeability of air pollution in Katowice Region (Central Europe, Southern Poland), 
Advanced Air Pollution, Dr. Farhad Nejadkoorki (Ed.), ISBN: 978-953-307-511-2, InTech, DOI: 10.5772/22013. (http://www.intechopen.com/books/advanced-air-pollution/ changeability-of-air-pollution-in-katowice-region-centraleurope-southern-poland-(07.09.2015))

Low, P.S. \& Hsu, G.J. (1990). Determination of atmospheric lead by Zeeman solid sampling graphite furnace atomic absorption spectrometry (GFAAS), Fresenius Journal of Analytical Chemistry, 337, pp. 299-305.

Marrero, J., Rebagliati, R.J., Gomez, D. \& Smichowski, P. (2005). A study of uniformity of elements deposition on glass fiber filters after collection of airborne particulate matter (PM-10), using a high-volume sampler, Talanta, 68, pp. 442-447.

Moura, M, Vasconcelos, M. \& Machado, A. (1987). Determination of lead in atmospheric aerosols by electrothermal atomization atomic-absorption spectrometry with direct introduction of filters into the graphite-furnace, Journal of Analytical Atomic Spectrometry, 2, pp. 451-454.

PN-EN 12341:2006a: Air quality - Determination of the PM10 fraction of suspended particulate matter - Reference method and field test procedure to demonstrate reference equivalence of measurement methods.

PN-EN 14907:2006b: Ambient air quality - Standard gravimetric measurement method for the determination of the PM2,5 mass fraction of suspended particulate matter.

Pöykiö, R., Peramaki, P. \& Ronkkomaki, H. (2003). The homogeneity of heavy metal deposition on glass fibre filters collected using a high-volume sampler in the vicinity of an opencast chrome mine complex at Kemi, Northern Finland, Analytical and Bioanalytical Chemistry, 375, pp. 476-481.

Prządka, Z., Skotak, K. \& Bruszewski, H. (2012). Uniformity of distribution of particulate matter on filters used in high volume samplers, Ochrona Środowiska i Zasobów Naturalnych, 54, pp. 236-247.

Regulation of the Ministry of Environment of 24 August 2012 concerning evaluation of substances levels in the air, Journal of Laws 2012, item 1031.
Regulation of the Minister of Environment of 26 January 2010 on the reference values for certain substances in the air (DzU Nr 16, poz. 87), Warszawa 2010

Rogula-Kozłowska, W., Błaszczak, B., Szopa, S., Klejnowski, K., Sówka, I., Zwoździak, A., Jabłońska, M. \& Mathews, B. (2013). $\operatorname{PM}(2.5)$ in the central part of Upper Silesia, Poland: concentrations, elemental composition, and mobility of components, Environmental Monitoring and Assessment, 185, pp. 581-601.

Rogula-Kozłowska, W., Kozielska, B. \& Klejnowski, K. (2013). Concentration, origin and health hazard from fine particlebound PAH at three characteristic sites in Southern Poland, Bulletin of Environmental Contamination And Toxicology, 91, pp. 349-355.

Rogula-Kozlowska, W., Blaszczak, B. \& Klejnowski, K. (2011). Concentrations of PM2.5, PM2.5-10 and PM-related elements at two heights in an urban background area in Zabrze (Poland), Archives of Environmental Protection, 37, pp. 31-47.

Steinhoff, G., Haupt, O. \& Dannecker, W. (2000). Fast determination of trace elements on aerosol-loaded filters by X-ray fluorescence analysis considering the inhomogeneous elemental distribution, Fresenius Journal of Analytical Chemistry, 366, pp. 174-177.

Viana, M., Kuhlbusch, T.A.J., Querol, X., Alastuey, A., Harrison, R.M., Hopke, P.K., Winiwarter, W., Vallius, W., Szidat, S., Prévôt, A.S.H., Hueglin, C., Bloemen, H., Wåhlin, P., Vecchi, R., Miranda, A.I., Kasper-Giebl, A., Maenhaut, W. \& Hitzenberger, R. (2008). Source apportionment of particulate matter in Europe: A review of methods and results, Aerosol Science, 39, pp. 827-849.

Yang, X.J., Wan, P.Y. \& Foley, R. (2012). Effect of sample digestion, air filter contamination, and post-adsorption on the analysis of trace elements in air particulate matter, Clean-Soil, Air, Water, 40, pp. 1217-1221.

Zdrojewski, A., Quickert, N. \& Dubois, L. (1973). The accurate measurement of cadmium in airborne particulates, International Journal of Environmental Analytical Chemistry, 2, pp. 331-341.

\title{
Rozkład metali na powierzchni filtrów kwarcowych stosowanych do poboru pyłu zawieszonego
}

\begin{abstract}
Streszczenie: Praca miała na celu zbadanie rozkładu metali na powierzchni filtrów kwarcowych pokrytych pyłem zawieszonym zebranym przy użyciu wysoko- oraz niskoprzepływowych analizatorów powietrza. Rozkład badano przy użyciu dwóch różnych systemów podpróbkowania filtrów. Każdą podpróbkę mineralizowano w kwasie azotowym w piecu mikrofalowym. Analizę przeprowadzono techniką absorpcyjnej spektroskopii atomowej $\mathrm{z}$ atomizacją elektrotermiczną GT-AAS, za pomocą której oznaczano następujące pierwiastki: $\mathrm{As}, \mathrm{Cd}, \mathrm{Pb}$ i Ni. Walidację procedury analitycznej przeprowadzono przy użyciu certyfikowanego materiału odniesienia NIES28 Urban Aerosols. Założono, że metal jest rozłożony na powierzchni filtra równomiernie, jeśli jego znormalizowane stężenie na pojedynczej podpróbce mieści się w zakresie $\pm 15 \%$ średniego stężenia na całym filtrze. Ponieważ wartości znormalizowanych stężeń metali przekraczały ten zakres, wskazywało to jednoznacznie na nierównomierny ich rozkład na powierzchni filtrów. Nie stwierdzono statystycznie istotnych różnic w stężeniach metali pomiędzy poszczególnymi fragmentami filtrów w funkcji ich położenia względem średnicy filtrów.
\end{abstract}

